\title{
Tuberculosis and diabetes mellitus: sociodemographic and clinical profile in Brazilian municipalities
}

\author{
Tuberculose e diabetes mellitus: perfil sociodemográfico \\ e clínico em municípios brasileiros \\ Tuberculosis y diabetes mellitus: perfil sociodemográfico \\ y clínico en municipios brasileños
}

\section{Aline Ale Beraldo ${ }^{a}$ \\ Rubia Laine de Paula Andrade ${ }^{b}$ Érika Simone Galvão Pinto ${ }^{c}$ \\ Reinaldo Antônio da Silva-Sobrinho ${ }^{d}$ Nanci Michele Saita ${ }^{b}$ Aline Aparecida Monroe ${ }^{b}$ Tereza Cristina Scatena Villa ${ }^{b}$}

\section{How to cite this article:} Beraldo AA, Andrade RLP, Pinto ESG, Silva-Sobrinho RA, Saita NM, Monroe AA. Tuberculosis and diabetes mellitus: sociodemographic and clinical profile in Brazilian municipalities. Rev Gaúcha Enferm. 2021;42:e20200247. doi: https://doi org/10.1590/1983-1447.2021.20200247 a Ministério da Saúde, Departamento de Imunização e Doenças Transmissíveis, Coordenação Geral do Programa Nacional de Imunizações. Brasilia, Distrito Federal, Brasil.

' Universidade de São Paulo (USP), Escola de Enfermagem de Ribeirão Preto, Departamento de Enfermagem Materno Infantil e Saúde Pública. Ribeirão Preto, São Paulo, Brasil.

Universidade Federal do Rio Grande do Norte (UFRN), Centro de Ciências da Saúde, Departamento de Enfermagem. Natal, Rio Grande do Norte, Brasil.

Universidade Estadual do Oeste do Paraná (UNIOESTE), Centro de Educação, Letras e Saúde. Foz Iguaçu, Paraná, Brasil.

\section{ABSTRACT}

Objective: To analyze the sociodemographic and clinical profile of tuberculosis cases with Diabetes Mellitus in Brazilian municipalities in the states of São Paulo, Paraná and Rio Grande do Norte.

Method: This is a cross-sectional study, whose population consisted of tuberculosis cases notified between 2010 and 2014. Data were collected from secondary sources. In the data analysis, descriptive analysis and multiple correspondence analysis techniques were used.

Results: The prevalence of diabetes among tuberculosis cases ranged from $4.5 \%$ to $13.4 \%$ in the municipalities. Evidence of an association was observed between tuberculosis/diabetes comorbidity and female population, age of 61 years or more, low schooling, negative HIV/AIDS, longer treatment time, self-administered treatment and cure.

Conclusion: The study showed a greater cure outcome in the profile of people with tuberculosis/diabetes comorbidity, even among those on a self-administered regime, which could favor the development of specific guidelines for the management of tuberculosis in these people.

Keywords: Tuberculosis. Diabetes mellitus. Health profile.

\section{RESUMO}

Objetivo: Analisar o perfil sociodemográfico e clínico dos casos de tuberculose com Diabetes Mellitus em municípios brasileiros dos estados de São Paulo, Paraná e Rio Grande do Norte.

Método: Estudo transversal, cuja população constituiu de casos de tuberculose notificados entre os anos de 2010 a 2014. Foram coletados dados de fontes secundárias. Na análise dos dados, foram utilizadas técnicas de análise descritiva e análise de correspondência múltipla.

Resultados: A prevalência de diabetes entre os casos de tuberculose variou de 4,5\% a 13,4\% nos municípios. Foram observadas evidências de associação entre comorbidade tuberculose/diabetes e população feminina, idade de 61 anos ou mais, baixa escolaridade, HIV/Aids negativo, maior tempo de tratamento, tratamento autoadministrado e cura.

Conclusão: Estudo mostrou maior desfecho cura no perfil das pessoas com comorbidade tuberculose/diabetes mesmo entre aquelas em regime autoadministrado, o que poderia favorecer a elaboração de diretrizes específicas para o manejo da tuberculose nessas pessoas. Palavras-chave: Tuberculose. Diabetes mellitus. Perfil de saúde.

\section{RESUMEN}

Objetivo: Analizar el perfil sociodemográfico y clínico de los casos de tuberculosis con Diabetes Mellitus en municipios de tres estados brasileños.

Método: Estudio transversal, cuya población consistió en casos de tuberculosis notificados entre 2010 y 2014. Se recopilaron datos de fuentes secundarias. En el análisis de datos, se utilizaron análisis descriptivos y técnicas de análisis de correspondencia múltiple. Resultados: La prevalencia de diabetes entre los casos de tuberculosis osciló entre el 4,5\% y el 13,4\%. Se observaron pruebas de una asociación entre la comorbilidad de la tuberculosis/diabetes y la población femenina, edad de 61 años o más, baja escolarización, VIH/ SIDA negativo, tiempo de tratamiento más largo, tratamiento autoadministrado y curación.

Conclusión: El estudio mostró un mayor porcentaje de resultado cura en el perfil de las personas con tuberculosis/diabetes, incluso entre los que están en régimen autoadministrado, lo que puede favorecer el desarrollo de directrices específicas para el manejo de la tuberculosis en estas personas.

Palabras clave: Tuberculosis. Diabetes mellitus. Perfil de salud. 


\section{口INTRODUCTION}

Tuberculosis (TB) is an infectious disease and its complexity represents one of the most serious and persistent contemporary public health problems worldwide ${ }^{(1-2)}$, even with effective chemotherapy, diagnostic methods and prevention widely known ${ }^{(3)}$. Until 2015, the TB incidence coefficient had been decreasing in Brazil, however, since 2016 this coefficient has been increasing ${ }^{(4)}$.

In the literature, there is strong evidence for the association between TB and Diabetes Mellitus (DM), showing that this condition increases the risk of developing $\mathrm{TB}^{(1-5)}$. The sustained hyperglycemia (glycated hemoglobin $\geq 7.0$ ) is associated with an increased prevalence of $\mathrm{TB}^{(6)}$. Such risk is worrying, since the projected prevalence of DM in the world was to increase from 172 million in 2000 to 592 million in 2035, however, it has already reached 463 million cases in 2019(7).

In Brazil, the estimated number of DM cases among people aged 20 to 79 years is 17.8 million $^{(7)}$. From these people, half are not diagnosed, so the association between TB and DM may be underestimated. A study in Brazil showed a prevalence of DM in people with TB in the period 20072011 of $7.2 \%{ }^{(8)}$, in Peru it was $13.97 \%{ }^{(9)}$.

The relationship between DM and TB can be explained in the following ways: DM is responsible for a dysfunction of the immune system that can increase susceptibility to $\mathrm{TB}^{(6)}$; the DM can modify the clinical presentation of $\mathrm{TB}^{(10)}$; there are positive bacilli in sputum samples and even 30 days after starting TB treatment ${ }^{(11)}$; the presence of DM increases the severity and the risk of unfavorable treatment outcomes, such as TB mortality ${ }^{(1,5)}$; people with DM and TB have more difficulty controlling blood glucose levels compared to a person with DM without $\mathrm{TB}^{(1)}$.

In addition to clinical issues, social and behavioral aspects can favor the relationship between DM and TB. A meta-analysis showed that people with DM in low or middle-income countries show higher risk of TB than in high-income countries $^{(12)}$. In low and middle-income countries, about $95 \%$ of people with TB live and 70\% of people with DM, resulting from the growth of the obesity epidemic, industrialization, urbanization and changes in lifestyle ${ }^{(7,12-13)}$.

In this sense, this study aimed to analyze the sociodemographic and clinical profile of tuberculosis cases with Diabetes Mellitus in Brazilian municipalities in the states of São Paulo (SP), Paraná (PR) and Rio Grande do Norte (RN), based on the hypothesis that the profile of people with these diseases differs from those with only TB.

\section{METHODS}

This is a cross-sectional epidemiological study, with a study population composed of TB cases resident in the cities of Campinas (SP), Ribeirão Preto (SP), Almirante Tamandaré (PR), Curitiba (PR), Foz do Iguaçu (PR), Londrina (PR), Paranaguá $(P R)$, Pinhais (PR), Piraquara (PR), Natal (RN) and Parnamirim (RN), notified in the respective TB information systems between the years 2010 to 2014, aged equal or over 18 years. The municipalities studied in Paraná and Rio Grande do Norte were chosen because they were all priorities for TB control in these states in 2014 $4^{(14)}$. In the state of São Paulo, due to the size of its population, two of the 42 priority cities for TB control were selected, which would have to present a number of new TB cases similar to at least one of the other states studied.

In the year 2014 (the last year of the period considered for data collection), Campinas (SP), presented 339 new cases of TB, with an incidence coefficient of 30.9 cases for every 100,000 inhabitants. Ribeirão Preto (SP) presented 162 new cases and an incidence of 24.9 cases per 100,000 inhabitants. In Almirante Tamandaré (PR), the municipality presented 24 new TB cases, with an incidence coefficient of 22.8 cases for every 100,000 inhabitants. Curitiba (PR) presented 389 new cases and an incidence of 21.9 cases per 100,000 inhabitants. Foz do Iguaçu (PR) had 128 new cases and an incidence coefficient of 50.1 cases per 100,000 inhabitants. Londrina (PR) presented 116 new cases, with an incidence coefficient of 22.5 cases for every 100,000 inhabitants. Paranaguá (PR) presented 121 new cases, an incidence coefficient of 84.9 cases for every 100,000 inhabitants. Pinhais (PR) presented 81 new cases, an incidence coefficient of 67.9 cases per 100,000 inhabitants. Piraquara (PR) presented 27 new cases, an incidence coefficient of 28.1 cases for every 100,000 inhabitants. Natal (RN) had 376 new TB cases and the incidence was 46.0 cases for every 100,000 inhabitants. Parnamirim (RN) presented 69 new cases and an incidence coefficient of 32.2 cases per 100,000 inhabitants ${ }^{(14)}$.

In the state of São Paulo, the TB-WEB (Tuberculosis Notification and Monitoring System) was used as a source of the study data, and in Campinas, the databank was extracted on May 23, 2016, and in Ribeirão Preto on January 29, 2016. In the states of Paraná and Rio Grande do Norte, data extraction was performed, respectively, on January 11, 2016 and February 18, 2016 through Sinan - TB (Information System for Notifiable Diseases - Tuberculosis).

For the definition of study participants, some exclusion criteria were defined, as shown in chart 1. 


\begin{tabular}{|l|c|c|c|}
\hline \multicolumn{1}{|c|}{ State of residence (population) } & $\begin{array}{c}\text { São Paulo } \\
\mathbf{( 2 , 8 2 6 )}\end{array}$ & $\begin{array}{c}\text { Paraná } \\
\mathbf{( 5 , 9 5 3 )}\end{array}$ & $\begin{array}{c}\text { Rio Grande } \\
\text { do Norte } \\
\mathbf{( 2 , 8 5 7 )}\end{array}$ \\
\hline Exclusion criteria & 198 & 260 & 184 \\
\hline Aged under 18 years old & 145 & 197 & 47 \\
\hline Having as outcome a change of diagnosis & 27 & 233 & 497 \\
\hline Having as outcome a transfer & - & 95 & 577 \\
\hline Not presenting information on Diabetes & $\mathbf{2 , 4 5 6}$ & $\mathbf{5 , 1 6 8}$ & $\mathbf{1 , 5 5 2}$ \\
\hline Study participants & &
\end{tabular}

Chart 1 - Exclusion criteria for tuberculosis cases, according to the Brazilian state of residence Source: Research data, 2020.

The variables used in the study were related to socio-demographic (race/color, age, gender, schooling) and clinical information (date of start and end of treatment - time of treatment, clinical form, diabetes mellitus, HIV, AIDS, type, and treatment outcome).

To proceed with data analysis, it was necessary to use the "SINAN NET Data Dictionary"for TB to convert the information that was presented in codes. Descriptive analysis techniques (frequency distribution, measures of central tendency and variability) were used to analyze the prevalence of DM among notified TB cases, as well as the sociodemographic and clinical characterization of the cases, according to the condition of having or not comorbidity with DM.

Subsequently, a multiple correspondence analysis was performed to identify variables associated with the condition of having or not comorbidity with DM. For having less stability in the multidimensional space of the factorial plans, the variables that showed low quality $(<0.1)$ were excluded and did not appear in them. The same occurred with some response categories.

After approval by the Municipal Health Offices of Campinas and Ribeirão Preto, and by the State Health Offices of Paraná and Rio Grande do Norte, the research project was submitted to and approved by the Ethics Committee of the Ribeirão Preto School of Nursing, Universidade de São Paulo, under protocol CAAE 49954715.3.0000.5393.

\section{RESULTS}

Considering the study population, the prevalence of DM among TB cases from 2010 to 2014 was higher in Campinas
(7.4\%) in the state of São Paulo, in Londrina (8.8\%) in Paraná and in Natal (13.4\%) in Rio Grande do Norte. The municipalities of Rio Grande do Norte were the ones with the highest prevalence of DM (table 1).

As for the sociodemographic characterization of the studied TB cases, it was found that in the states of São Paulo and Paraná the majority were white race and in Rio Grande do Norte brown. The age group of people with DM comorbidity was higher (41 years or more) in all states. The predominant gender was male, and the level of schooling was low, however, this variable had a lot of ignored data (table 2).

It was possible to identify that in all states, most people had a treatment time of up to six months and the pulmonary clinical form of TB. Regarding HIV and AIDS, most cases in all states did not have co-infection. With the exception of Rio Grande do Norte, the most indicated treatment for TB cases in the states was directly observed. Cure was the predominant outcome in all states, including among cases with DM (Table 3).

The factorial plan (figure 1) presents the factors associated with TB cases with and without DM and with the municipalities of the states of São Paulo, Paraná and Rio Grande do Norte.

In the state of São Paulo, it was identified evidence that DM cases are associated with age over 60 years, race ignored, schooling ignored, HIV negative, AIDS negative, treatment time greater than 6 months and cure. Individuals who do not have DM and who live in Ribeirão Preto showed evidence of association with the age of 41 to 60 years, schooling from 1 to 8 years, ignored income, HIV positive, AIDS positive, type 
Table 1 - Prevalence of Diabetes Mellitus among notified tuberculosis cases, according to Brazilian states and municipalities in the period from 2010 to 2014

\begin{tabular}{|c|c|c|c|}
\hline State & Municipalities & $\begin{array}{l}\text { Number of } \\
\text { tuberculosis cases }\end{array}$ & $\begin{array}{c}\text { Prevalence of } \\
\text { Diabetes Mellitus }\end{array}$ \\
\hline \multirow{2}{*}{ São Pau } & Campinas & 1,566 & $7.4 \%$ \\
\hline & Ribeirão Preto & 890 & $5.7 \%$ \\
\hline \multirow{2}{*}{ Rio Gra } & Natal & 1,285 & $13.4 \%$ \\
\hline & Parnamirim & 267 & $9.0 \%$ \\
\hline \multirow{7}{*}{ Paraná } & Almirante Tamandaré & 106 & $7.6 \%$ \\
\hline & Curitiba & 2,355 & $7.2 \%$ \\
\hline & Foz do Iguaçu & 669 & $6.1 \%$ \\
\hline & Londrina & 797 & $8.8 \%$ \\
\hline & Paranaguá & 681 & $6.2 \%$ \\
\hline & Pinhais & 444 & $4.5 \%$ \\
\hline & Piraquara & 116 & $6.0 \%$ \\
\hline
\end{tabular}

Source: Research data, 2020.

of treatment without information, treatment time of 0 to 6 months. Campinas showed no evidence of association with any of these conditions.

Evidence was identified in the state of Paraná that people with DM who live in Foz do Iguaçu and Altamirante Tamandare were associated with the following conditions: female, age over 60 years old, individuals without schooling, HIV without information, AIDS without information and self-administered treatment. Individuals without DM showed evidence of an association with male gender, age 18 to 40, other race or brown, HIV and AIDS positive, directly observed treatment, treatment default and failure. Londrina, Piraquara, Pinhais, Paranaguá and Curitiba did not showed evidence of association with any of these conditions.

In Rio Grande do Norte, it was possible to identify evidence of an association between DM and the age of over 60 years and AIDS and HIV without information. Individuals without DM showed evidence of an association between the ages of 18 to 60 years and treatment failure. No municipality in that state was associated with any of these conditions.

\section{DISCUSSION}

The prevalence of DM among TB cases ranged from 4.5\% in the municipality of Pinhais (PR) to $13.4 \%$ in Natal (RN). However, there is doubt about the quality of data in Rio Grande do Norte, since 577 (20.2\%) people were excluded from the study for not presenting information about DM, raising a question that these may not be cases of $D M$, which would decrease its prevalence if they had been registered. As for the other states, Paraná has 1.6\% of non-registration of this variable and the state of São Paulo had 100\% of registration of the same.

In this way, the quality of the registry was assessed by a study published in 2017 and points out to the inadequate registration of DM cases in Sinan-TB. In this study, 13.0\% of the cases of comorbidity with DM were not informed as such $^{(15)}$. This shows the importance of identifying DM cases among TB cases and the adequate recording of information, which serve to guide health actions and policies.

On factorial plans, it was possible to see that older age (over 60 years) was determinant for the occurrence of DM 
Table 2 - Characterization of tuberculosis cases and tuberculosis cases with diabetes mellitus, according to sociodemographic variables, municipalities in three Brazilian states, 2010 to 2014

\begin{tabular}{|c|c|c|c|c|c|c|}
\hline \multirow[b]{3}{*}{ Variables } & \multicolumn{2}{|c|}{ São Paulo* } & \multicolumn{2}{|c|}{ Rio Grande do Norte ${ }^{* *}$} & \multicolumn{2}{|c|}{ Paraná*** } \\
\hline & TB & TB/DM & TB & TB/DM & TB & TB/DM \\
\hline & $\mathbf{N}(\%)$ & $N(\%)$ & $N(\%)$ & $N(\%)$ & $N(\%)$ & $N(\%)$ \\
\hline \multicolumn{7}{|l|}{ Race/Color } \\
\hline White & $1,001(43.7)$ & $73(43.7)$ & $390(28.8)$ & $53(27.0)$ & $3,236(67.3)$ & $274(76.5)$ \\
\hline Brown & $496(21.7)$ & 33(19.8) & $770(56.8)$ & $118(60.2)$ & 989(20.6) & $46(12.8)$ \\
\hline Other & $252(11.0)$ & $10(6.0)$ & $141(10.4)$ & $17(8.7)$ & $396(8.2)$ & $21(5.9)$ \\
\hline Ignored & $540(23.6)$ & $51(30.5)$ & $55(4.0)$ & $08(4.1)$ & 189(3.9) & $17(4.8)$ \\
\hline
\end{tabular}

Age (years)

18 to 40

41 to 60

61 or more

Ignored

\section{Gender}

Male

Female

Schooling (years)

\begin{tabular}{|c|c|c|c|c|}
\hline None & $62(2.7)$ & $08(4.8)$ & $85(6.3)$ & $26(13.2)$ \\
\hline 1 to 8 & $782(34.2)$ & $47(28.1)$ & $421(31.0)$ & $61(31.1)$ \\
\hline 9 to 12 & $445(19.4)$ & $14(8.4)$ & $347(25.6)$ & $51(26.1)$ \\
\hline 13 or more & $162(7.1)$ & 08(4.8) & $95(7.0)$ & 09(4.6) \\
\hline Ignored & $838(36.6)$ & $90(53.9)$ & $408(30.1)$ & $49(25.0)$ \\
\hline
\end{tabular}

$02(0.1)$

674(29.4)

$\begin{array}{llllll}1,153(50.4) & 27(16.2) & 743(54.8) & 31(15.8) & 2,672(55.6) & 43(12.0) \\ 870(38.0) & 98(58.7) & 461(34.0) & 95(48.5) & 1,691(35.2) & 188(52.5) \\ 264(11.5) & 42(25.1) & 152(11.2) & 70(35.7) & 447(9.2) & 127(35.5)\end{array}$

$\begin{array}{llllll}1,615(70.6) & 110(65.9) & 888(65.5) & 110(56.1) & 3,296(68.5) & 242(67.6) \\ 674(29.4) & 57(34.1) & 468(34.5) & 86(43.9) & 1,514(31.5) & 116(32.4)\end{array}$


Table 3 -Characterization of tuberculosis cases and tuberculosis cases with diabetes mellitus, according to clinical variables, municipalities in three Brazilian states, 2010 to 2014

\begin{tabular}{|c|c|c|c|c|c|c|c|}
\hline & \multirow[t]{2}{*}{ States } & \multicolumn{2}{|c|}{ São Paulo* } & \multicolumn{2}{|c|}{ Rio Grande do Norte ${ }^{* *}$} & \multicolumn{2}{|c|}{ Paraná ${ }^{* * *}$} \\
\hline & & $\mathrm{TB}^{4}$ & TB/DM ${ }^{5}$ & $\mathrm{~TB}^{4}$ & TB/DM ${ }^{5}$ & $\mathrm{~TB}^{4}$ & TB/DM ${ }^{5}$ \\
\hline Variables & & N (\%) & N (\%) & N (\%) & N (\%) & N (\%) & N (\%) \\
\hline
\end{tabular}

Treatment Time

$\begin{array}{lllllll}0 \text { to } 6 \text { months } & 1,459(63.7) & 113(67.7) & 1,008(74.3) & 118(60.2) & 3,167(65.8) & 229(64.0) \\ \text { Over } 6 \text { months } & 830(36.3) & 54(32.3) & 348(25.7) & 78(39.8) & 1,643(34.2) & 129(36.0)\end{array}$

\section{Clinical form}

Pulmonary

$1,874(81.9) \quad 145(86.2)$

$1176(86.7)$

183(93.4)

3,894(80.9)

304(84.9)

Extrapulmonary

415(18.1) 22(13.2)

180(13.3)

13(6.6)

916(19.1)

$54(15.1)$

\section{HIV}

Positive

472(20.6)

06(3.6)

134(9.9)

08(4.1)

968(20.1)

18(5.1)

Negative

$1,629(71.2)$

153(91.6)

702(51.8)

97(49.5)

$3,351(69.7)$

295(82.3)

No Information

188(8.2)

08(4.8)

520(38.3)

$91(46.4)$

491(10.2)

$45(12.6)$

\section{AIDS}

Positive

456(19.9)

05(3.0)

128(9.4)

07(3.6)

934(19.4)

16(4.5)

Negative

$1,833(80.1)$

162(97.0)

868(64.0)

118(60.2)

3,734(77.6)

319(89.1)

No Information

360(26.6)

$71(36.2)$

142(3.0)

23(6.4)

\section{Type of Treatment}

Directly Observed

$1,709(74.7) \quad 131(78.4) \quad 464(34.2)$

61(31.1)

3,842(79.4)

293(81.8)

Self-Administered

$339(14.8)$

20(12.0)

748(55.2)

120(61.2)

744(15.5)

$47(13.1)$

No Information

$241(10.5) \quad$ 16(9.6)

144(10.6)

15(7.7)

224(4.7)

18(5.1)

\section{Treatment outcome}

\begin{tabular}{lcccccc} 
Cure & $1,793(78.3)$ & $128(76.6)$ & $1,034(76.3)$ & $152(77.6)$ & $3,618(75.2)$ & $276(77.1)$ \\
Default & $261(11.4)$ & $10(6.0)$ & $204(15.0)$ & $10(5.1)$ & $561(11.7)$ & $20(5.6)$ \\
Death & $224(9.8)$ & $27(16.2)$ & $108(8.0)$ & $29(14.8)$ & $569(11.8)$ & $52(14.5)$ \\
Failure & $11(0.5)$ & $02(1.2)$ & $10(0.7)$ & $05(2.5)$ & $62(1.3)$ & $10(2.8)$ \\
\hline
\end{tabular}

Source: Research data, 2020.

Legend: TB - Tuberculosis Cases; TB/DM - Tuberculosis Cases with Diabetes Mellitus.

*Two municipalities in the state (Campinas and Ribeirão Preto).

"*All priority municipalities for the control of Tuberculosis in the state in 2014 (Natal and Parnamirim).

“**All priority municipalities for the control of Tuberculosis in the state in 2014 (Almirante Tamandaré, Curitiba, Foz do lquaçu, Londrina, Paranaguá, Pinhais and Piraquara). 

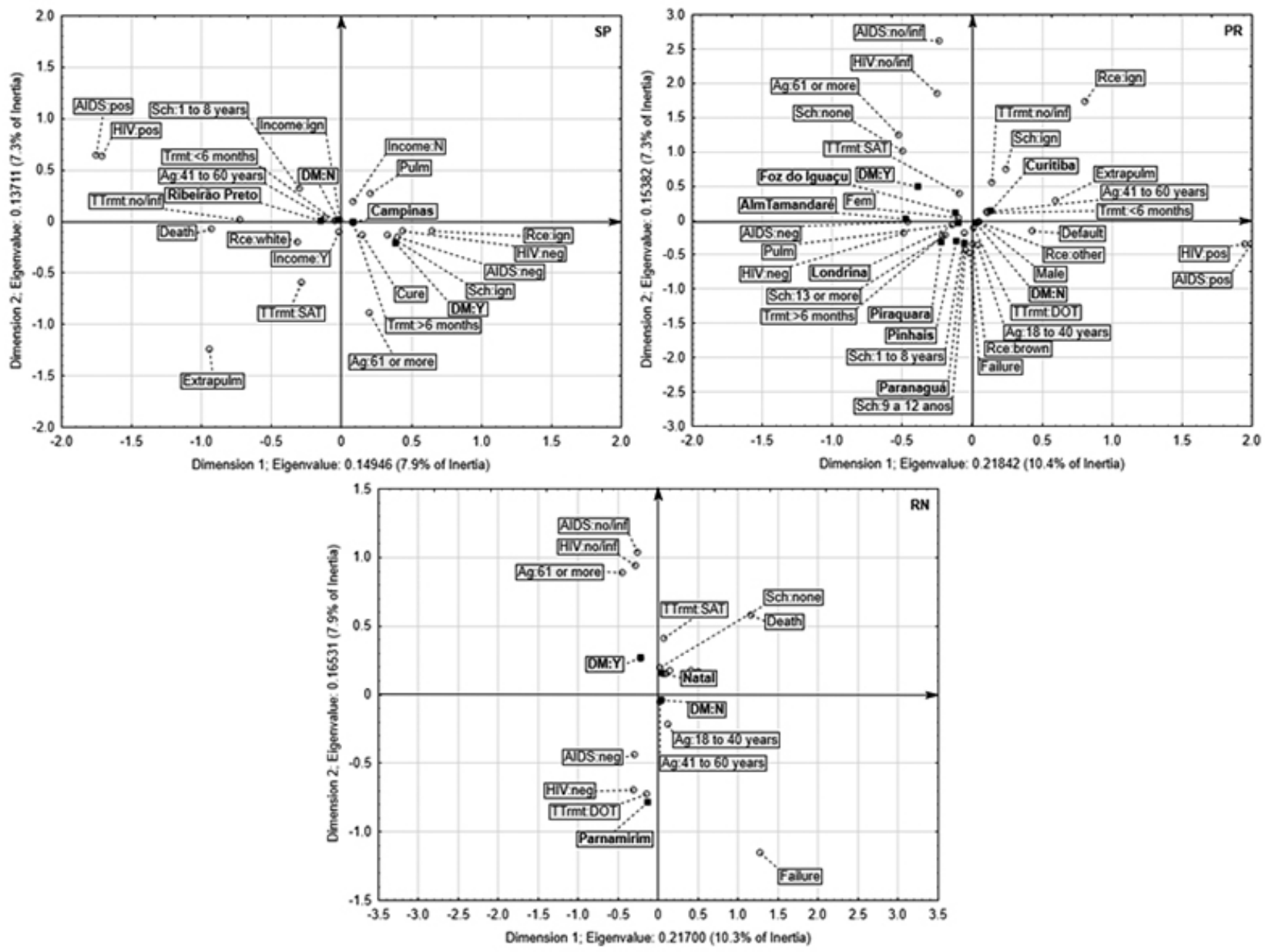

Figure 1 - Factorial plan of tuberculosis cases with and without diabetes mellitus and factors associated with the study municipalities from 2010 to 2014

Source: Research data, 2020

Legend: States: São Paulo (SP), Paraná (PR), Rio Grande do Norte (RN); Diabetes Mellitus (DM); Race (Rce); Age (Ag); Schooling (Sch); Treatment time (Trmt); Type of treatment (TTrmt). Response categories: Yes(Y); No (N); ignored (ign); female (Fem), male (Male); pulmonary (Pulm); extrapulmonary (Extrapulm); positive (pos), negative (neg), no information (no/inf); self-administered treatment (SAT); directly observed treatment (DOT).

among TB cases in the three studied states, in agreement with other studies in Brazil ${ }^{(8-10)}$, including one cross-sectional study, whose results from the multivariate analysis showed that people aged 60 or more had a greater association with the comorbidity $(P R=17.49 ; C l \% 15.26-20.05)^{(8)}$.

Other sociodemographic characteristics that overlapped the condition of having DM were female and lack of schooling in the state of Paraná. It is known that DM affects women and people with less schooling and, therefore, the result found in Paraná is not surprising. To illustrate this fact, it is worth referring to a study published in 2017 with data from a Brazilian national survey, which shows a higher prevalence of DM cases in females (8.2\%; 95\% Cl 7.6-8.9) compared to males (6.6\%; 95\% Cl 5.9-7.3) and in people with schooling from 0 to 4 years $(10.2 \% ; 95 \%$ Cl 9.4-11.0) compared to 5 to
7 years $(6.0 \% ; 95 \% \mathrm{Cl} 5.1-6.9)$ and greater than or equal to 8 years (5.1\%; 95\% Cl 4.3-5.8) $)^{(16)}$.

Still in relation to socioeconomic characteristics, it is worth highlighting the race and schooling ignored in the state of São Paulo as aspects associated with DM in people with TB. Once again, the issue of the quality of the information record appears as a limiting factor of the results themselves, which also happens in relation to the status of HIV/AIDS in the states of Paraná and Rio Grande do Norte.

A study that evaluates the records of information about TB points out that the professionals' carelessness of filling in data can affect the proper monitoring of cases, in addition to being a picture of the non-use of information by them, or their lack of awareness regarding the importance of records in planning and evaluation activities ${ }^{(17)}$. 
In the state of São Paulo, it was verified an association between the condition of having DM and not having HIV/ AIDS. This can be identified in a nationwide study carried out from 2007 to 2011, which showed that people with positive results for HIV were less associated with TB-DM comorbidity $(\mathrm{PR}=0.53 ; 95 \% \mathrm{Cl} 0.49-0.58)^{(8)}$.

Regarding the variables related to TB treatment, the state of São Paulo showed evidence of an association between DM cases and treatment time greater than 6 months and cure outcome. Such a result makes sense since the longer the treatment, the closer to the cure the person is. A study carried out in Brazil showed that re-entry after treatment default ( $P R=0.66 ; 95 \% \mathrm{Cl} 0.57$ - 0.76) and treatment default $(P R=0.79 ; 95 \% \mathrm{Cl} 0.72-0.87)$ were also inversely associated in people with the comorbidity ${ }^{(8)}$. On the other hand, contrary to some authors ${ }^{(1)}$ mentioned in the introduction of this article, it seems that DM was not an aspect that led to unfavorable treatment outcomes.

Corroborating the results of the present study, other authors mention that cases of treatment default were inversely associated with people with DM when compared to cure ${ }^{(8,15)}$. In the present study, to further confirm the predominance of cure among DM cases, it was verified in the state of Paraná that people without such comorbidity were associated with treatment default and failure.

Another result that draws attention is the fact that the cases of TB/DM in the state of Paraná present evidence of association with self-administered treatment. Thus, in order to achieve a cure, the hypothesis arises that these people have a greater attitude towards the search for knowledge about TB as a new condition to be faced, and for self-care, which in a way, may be inducing greater adherence to treatment.

However, it must be evidenced the strong recommendation of the World Health Organization, given the high burden of the two diseases in developing countries, including Brazil, about the importance of implementing a collaborative structure between TB and DM programs for carrying out of DOT during TB treatment ${ }^{(18)}$.

The only municipalities that appear attributed to the same conditions associated with the DM are Foz do Iguaçu and Almirante Tamandaré. However, the study in the different states and municipalities was essential for the construction of the profile of the person affected by the TB/DM comorbidity. Thus, given the prevalence of DM among TB cases and the profile of the cases, it would be important for municipalities to jointly manage both conditions studied ${ }^{(8)}$. Thus, it is worth emphasizing the importance of screening for DM among diagnosed TB cases, since the clinical management and control of one of the conditions can contribute to the management of the other and vice versa ${ }^{(18-19)}$.

\section{CONCLUSION}

The study showed some aspects related to the profile of TB/DM comorbidity cases and among them, the following stand out: it affects more the female population, older age, low schooling level, people not infected with HIV/AIDS and results that refer to treatment adherence, even if self-administered and, consequently, to cure. It was also verified that the participation of several municipalities was important for the construction of this profile, in addition to emphasizing the importance of proper registration of information.

Given the need for new ways of coping with TB, the study provides a basis that could favor the development of more specific actions for the proper management of TB in association with DM, considering the specificities of each studied location. This is stated, since, despite the achievement of established goals by the End TB strategy (2015-2035), Brazil has shown, over the years, modest improvements in its epidemiological and operational indicators, which difficults to reach the national target effort to end the disease as a public health problem.

Regarding study limitations, a possible information bias stands out, due to the use of secondary data and also because the DM is referred to and has not been proven with exams.

\section{$\square$ REFERENCES}

1. Nascimento CV, Soares SM. [Co-management of tuberculosis and diabetes: an integrative review]. Rev Panam Salud Publica. 2019;43:e21. Spanish. doi:https:// doi.org/10.26633/RPSP.2019.21

2. Kanchar A, Swaminathan S. Tuberculosis control: WHO perspective and guidelines. Indian J Pediatr. 2019;86(8):703-6. doi: https://doi.org/10.1007/ s12098-019-02989-2

3. Ministério da Saúde (BR); Secretaria de Vigilância em Saúde; Departamento de Vigilância das Doenças Transmissíveis. Manual de Recomendações para 0 Controle da Tuberculose no Brasil. 2. ed atual. Brasília, DF; 2019 [cited 2020 Apr 22]. Available from: https://bvsms.saude.gov.br/bvs/publicacoes/ manual_recomendacoes_controle_tuberculose_brasil_2_ed.pdf

4. Ministério da Saúde (BR); Secretaria de Vigilância em Saúde. Vigilância em saúde no Brasil 2003|2019: da criação da Secretaria de Vigilância em Saúde aos dias atuais. Bol Epidemiol. 2019 set [cited 2020 Jul 1];50(n.esp):1-154. Available from: https:// ameci.org.br/wp-content/uploads/2019/09/boletim-especial-21ago19-web.pdf

5. Kumar NP, Fukutani KF, Shruthi BS, Alves T, Silveira-Mattos PS, Rocha MS, et al. Persistent inflammation during anti-tuberculosis treatment with diabetes comorbidity. elife. 2019;8:e46477. doi: https://doi.org/10.7554/eLife.46477

6. Almeida-Junior JL, Gil-Santana L, Oliveira CA, Castro S, Cafezeiro AS, Daltro C, et al. Glucose metabolism disorder is associated with pulmonary tuberculosis in individuals with respiratory symptoms from Brazil. PLoS One. 2016;11(4):e0153590. doi: https://doi.org/10.1371/journal.pone.0153590

7. International Diabetes Federation (BE). IDF Diabetes atlas 2019 [Internet]. 9th ed. Brussels: International Diabetes Federation; 2019 [cited 2020 Jul 1]. Available from: https://www.diabetesatlas.org/en/resources 
8. Abreu RG, Rolim LS, Sousa AIA, Oliveira MRF. Tuberculosis and diabetes: association with sociodemographic characteristics and diagnosis and treatment of tuberculosis. Brazil, 2007-2011. Rev Bras Epidemiol. 2020;23:e200009. doi: https://doi. org/10.1590/1980-549720200009

9. Calderon RI, Arriaga MB, Lopez K, Barreda NN, Sanabria OM, Froes Neto JF, et al. High prevalence and heterogeneity of daysglycemia in patients with tuberculosis from Peru: a prospective cohort study. BMC Infect Dis. 2019;19:799. doi: https:// doi.org/10.1186/s12879-019-4416-2

10. Gil-Santana L, Almeida-Junior UL, Oliveira CAM, Hickson LS, Daltro C, Castro S, et al. Diabetes is associated with worse clinical presentation in tuberculosis patients from Brazil: a retrospective cohort study. PLoS One. 201611(1):e0146876. doi: https://doi.org/10.1371/journal.pone.0146876

11. Barreda NN, Arriaga MB, Aliaga JG, Lopez K, Sanabria OM, Carmo TA, et al. Severe pulmonar radiological manifestations are associated with a distinct biochemical profile in blood of tuberculosis patients with dysglycemia. BMC Infect Dis. 2020;20:139. doi: https://doi.org/10.1186/s12879-020-4843-0

12. Al-Rifai RH, Pearson F, Critchley JA, Abu-Raddad LJ. Association between diabetes mellitus and active tuberculosis: a systematic review and meta-analysis. PLOS One. 2017Nov 21;12(11):e0187967. doi: https://doi.org/10.1371/journal. pone. 0187967

13. Workneh MH, Bjune GA, Yimer SA. Prevalence and associated factors of tuberculosis and diabetes mellitus comorbidity: a systematic review. PLOS One. 2017;12(4):e0175925. doi: https://doi.org/10.1371/journal.pone.0175925
14. Ministério da Saúde (BR). Secretaria de Vigilância em Saúde. Departamento de Vigilância das Doenças Transmissíveis. Panorama da tuberculose no Brasil: indicadores epidemiológicos e operacionais. Brasília, DF: Ministério da Saúde; 2014 [cited $2020 \mathrm{Jul}$ 1]. Available from: https://central3.to.gov.br/arquivo/400703/

15. Abreu RG, Sousa AIA, Oliveira MRF, Sanchez MN. Tuberculosis and diabetes: probabilistic linkage of databases to study the association between both diseases. Epidemiol Serv Saúde. 2017;26(2):359-68. doi: https://doi.org/10.5123/ s1679-49742017000200013

16. Flor LS, Campos MR. The prevalence of diabetes mellitus and its associated factors in the Brazilian adult population: evidence from a populationbased survey. Rev Bras Epidemiol. 2017;20(1):16-29. doi: https://doi. org/10.1590/1980-5497201700010002

17. Tomberg J0, Spagnolo LML, Valerão NB, Martins MDR, CardozoGonzales RI. Records in tuberculosis detection: perception of health professionals. Esc Anna Nery. 2019;23(3):e20190008. doi: https://doi. org/10.1590/2177-9465-ean-2019-0008

18. World Health Organization (CH), The International Union Against Tuberculosis and Lung Disease (FR). Collaborative framework for care and control of tuberculosis and diabetes. Geneva: WHO; 2011 [cited 2020 0ct 15]. Available from: https:// www.who.int/tb/publications/tb-diabetes-framework/en/

19. Pizzol D, Di Gennaro F, Chhaganlal KD, Fabrizio C, Monno L, Putoto G, et al. Tuberculosis and diabetes: current state and future perspectives. Trop Med Int Health. 2016;21(6):694-702. doi: https://doi.org/10.1111/tmi.12704 


\section{- Acknowledgments:}

The present work was carried out with the support of the Coordination for the Improvement of Higher Education Personnel - (Coordenação de Aperfeiçoamento de Pessoal de Nível Superior - CAPES) - Funding Code 001 and the National Council for Scientific and Technological Development (Conselho Nacional de Desenvolvimento Científico e Tecnológico - (NPq), which promoted a junior postdoctoral scholarship, process 402334/2014-0 and research support for Universal Public Notice, process 404124/2016-0.

\section{- Authorship contribution:}

Conceptualization: Aline Ale Beraldo, Rubia Laine de Paula Andrade, Tereza Cristina Scatena Villa.

Data curation: Aline Ale Beraldo, Rubia Laine de Paula Andrade, Tereza Cristina Scatena Villa.

Formal analysis: Aline Ale Beraldo, Rubia Laine de Paula Andrade, Tereza Cristina Scatena Villa.

Funding acquisition: Aline Ale Beraldo, Tereza Cristina Scatena Villa.

Investigation: Aline Ale Beraldo, Rubia Laine de Paula Andrade, Tereza Cristina Scatena Villa.

Methodology: Aline Ale Beraldo, Rubia Laine de Paula Andrade, Tereza Cristina Scatena Villa.

Project administration: Aline Ale Beraldo, Tereza Cristina Scatena Villa.

Resources: Aline Ale Beraldo, Rubia Laine de Paula

Andrade, Tereza Cristina Scatena Villa.

Software: Aline Ale Beraldo, Rubia Laine de Paula

Andrade, Tereza Cristina Scatena Villa.

Supervision: Aline Ale Beraldo, Rubia Laine de Paula Andrade, Tereza Cristina Scatena Villa.

Validation: Aline Ale Beraldo, Rubia Laine de Paula Andrade, Tereza Cristina Scatena Villa.

Visualization: Aline Ale Beraldo, Rubia Laine de Paula Andrade, Tereza Cristina Scatena Villa.

Writing-original draft: Aline Ale Beraldo, Rubia Laine de Paula Andrade, Tereza Cristina Scatena Villa.

Writing-review \& editing: Aline Ale Beraldo, Rubia Laine de Paula Andrade, Érika Simone Galvão Pinto, Reinaldo Antônio da Silva-Sobrinho, Nanci Michele Saita, Aline Aparecida Monroe, Tereza Cristina Scatena Villa.

\section{- Corresponding author:}

Aline Ale Beraldo

Email: li_aab@yahoo.com.br

\section{Associate editor:}

Rosana Maffacciolli

Editor-in-chief:

Approved: 11.04.2020
Maria da Graça Oliveira Crossetti 